\title{
Understanding Alignments and Mis-Alignments of Values to Better Craft Institutions in the Pastoral Drylands
}

\author{
Jane Addison ${ }^{1,2 *}$, Colin Brown ${ }^{3}$, Chris R. Pavey ${ }^{4}$, Enkh-Orchlon Lkhagvadorj ${ }^{5}$, \\ Duinkherjav Bukhbat ${ }^{5}$ and Lkhagvadorj Dorjburegdaa ${ }^{6}$
}

${ }^{1}$ College of Science and Engineering, James Cook University, Townsville, QLD, Australia, ${ }^{2}$ CSIRO Land and Water, Townsville, QLD, Australia, ${ }^{3}$ School of Agriculture and Food Sciences, The University of Queensland, Brisbane, QLD, Australia, ${ }^{4}$ CSIRO Land and Water, Darwin, NT, Australia, ${ }^{5}$ The Crawford School of Public Policy, Australian National University, Canberra, ACT, Australia, ${ }^{6}$ School of Economics and Business, Mongolian University of Life Sciences, Ulan Bator, Mongolia

Tensions in values between dryland pastoralists and non-pastoralists, and often between pastoralists themselves, are common globally. The re-imagining of grazed landscapes must recognize that current pastoralists have their own visions of what pastoralism does, can and should provide to both themselves and society at large. "Disrupters" may rapidly and permanently alter the social-ecological system but understanding pastoralist visions and values may help highlight effective and ethical mechanisms by which we can gently shift current systems toward socially re-imagined systems. Here we draw on two case studies from grazed dryland landscapes to highlight the ways in which understanding pastoralist values and visions could help with this shift. We choose case studies from contrasting institutional, cultural and economic contexts to better explore fit-for-purpose policy options. The first case study is from the typical and desert steppe of Mongolia, and the second from dryland Australia. Drawing on primary data and the literature, we explore in these contexts: what constitutes a meaningful livelihood for pastoralists? how might these imaginings align (or misalign) with the imaginings of the broader population? what inertia against future societal imaginings might a potential misalignment create? and how might policy provide a push (or pull) against such an inertia? We show that context-specific understandings of pastoralist values and visions can highlight appropriate policy options to encourage the movement of social-ecological systems toward those that are more socially desirable. However, the design of these options requires understanding unique combinations of pastoral and societal values, biophysical parameters and institutional contexts.

Keywords: livelihood, Mongolia, Australia, natural resource management, development, rangeland, social-ecological system

\section{INTRODUCTION}

Tensions in land-use related values, that is moral principles shaped by institutions, traditions, cultural beliefs and societal dynamics, are common between dryland pastoralists and other non-pastoral populations (Thebaud and Batterbury, 2001; Yongo et al., 2010). Unrecognized or unaddressed tensions have resulted in poor engagement or outcomes in natural resource 
management (Bhatnagar et al., 2006; Kearney et al., 2012), power inequities and elite capture of resources (Upton, 2009) and even violence (Thebaud and Batterbury, 2001; Hundie, 2010). The re-imagining of grazed landscapes, as a theme of this Special Edition, must recognize that current pastoralists have their own visions of what pastoralism does, can and should provide to both themselves and society at large, and that this will affect the implementation of livelihood strategies that align, or misalign, with these re-imagined landscapes.

Various institutional mechanisms have sought to bridge tensions in land-use related values between pastoral and nonpastoral interests. For example, payments for ecosystem services have sought to internalize the environmental impacts of pastoral production in a manner that shares costs between livestock producers and consumers (Ulvevadet and Hausner, 2011; Osano et al., 2013). Community based natural resource management, when designed to be inclusionary and participative, has sought to recognize local values and social norms whilst still addressing environmental goals that may better reflect broader societal values. However, such institutional mechanisms often preassume pastoralist understandings of meaningful livelihoods, and the values that inform them. The assumption that financial incentives are the most useful lever for changing behavior in the case of payments for ecosystem services has been challenged (Cocklin et al., 2007; Van Hecken and Bastiaensen, 2010; Moon and Cocklin, 2011). Similarly, the notion of spatially and temporally bounded communities with defined and accepted social norms has been critiqued in the case of community based natural resource management (Hogg, 1992; Leach et al., 2009).

Institutions that seek to move grazed landscapes toward socially re-imagined systems must understand the aspirations of pastoralists. Private and public objectives for grazing must be integrated into emerging institutional and market structures, with management of pastoral land seen as a shared, mainstream land management issue for society (MacLeod and McIvor, 2006). "Disrupters" may rapidly and permanently alter the social-ecological system but understanding pastoralist livelihood visions and values may help highlight effective and ethical mechanisms by which we can shift current systems toward those that are socially re-imagined. Drawing on primary data from two case studies and the peer reviewed literature more broadly, we explore: what constitutes a meaningful livelihood for pastoralists? how might these imaginings align (or misalign) with the imaginings of the broader population? what inertia against future societal imaginings might a potential misalignment create? and how might policy provide a push (or pull) against such an inertia?

\section{APPROACH \\ Theoretical Framing}

Livelihoods are comprised of the capabilities, assets (including both material and social) and activities required for a means of living (Chambers and Conway, 1992). The term is recognized as being multidimensional, including economic, political, cultural, social and environmental aspects. A diversity of livelihood activities in a complex bricolage (Scoones, 2009) leads to a diversity of outcomes and outcome pathways, challenging a simplistic understanding of what constitutes livelihood development. However, the ability and opportunities available to cope with multi-level and multi-scaled shocks and stresses affecting stocks and flows of food and cash are an important component of livelihood sustainability (Chambers and Conway, 1992). This is particularly pertinent in complex social-ecological systems (Ostrom, 2019), like those in the pastoral drylands, which are prone to periodic shocks such as extreme weather events.

Development theory and practice increasingly centers on an understanding of livelihood and livelihood development and on the ability to improve people's choices, capability, freedoms and equity (Sen, 1999). The centring of individual choice in livelihood and livelihood development means that what constitutes a "meaningful" livelihood is inherently valuebased. Understanding what constitutes a meaningful livelihood therefore requires understanding not only the means that people have to subsist, but also the meanings with which different subsistence strategies are imbued (Taylor, 2002). Uncertainties, such as erratic precipitation, combined with emerging opportunities, influence the ways in which material and non-material resources are used, and on the choices that individuals make between different sets of values that are associated with the use of these resources (Hebinck and Bourdillon, 2002). That is, values ultimately affect material subsistence strategies.

The values and subsequent livelihood strategies of an individual or local community can misalign with the values of society more broadly. Access to the informational, financial and institutional resources required to exercise developmental freedom is necessary for livelihood development (Ribot and Peluso, 2003). Access to many of these resources is controlled or administered by the State and thus tends to privilege societal values over that of special interest groups (see Addison et al., 2019 for examples from Australia). However, it is also the point at which the State can facilitate access to particular resources for the benefit of both livelihood development, and broader societal natural resource goals. That is, it is one way in which the State can help shift land-use toward broader societal goals. Ideally, participative and deliberative processes should be used so that a re-imagined landscape is collectively re-imaged, inclusive of the values and aspirations of those most affected. An important step in such a process is understanding the complex and contextually grounded nature of what constitutes livelihood outcomes, pathways and impacts for local people. This approach also includes a recognition of the way in which the values of local people may be in tension with broader societal values. We now use two pastoral case studies to explore how particular livelihood visions and values can align (or misalign) with broader societal values, and the ways in which institutional levers might better recognize pastoralists' livelihood imaginings.

\section{Data Sources}

The Australian case study draws upon the published literature, including Addison and Pavey (2017). The Mongolian case study draws upon the published literature that includes a series of published book chapters: Addison et al. (2020a), Addison et al. 
TABLE 1 | Summary of case study areas, including some examples of key biophysical, socioeconomic and value-based characteristics.

\begin{tabular}{|c|c|c|}
\hline & Mongolian steppe & Australian drylands \\
\hline $\begin{array}{l}\text { Key biophysical } \\
\text { characteristics }\end{array}$ & $\begin{array}{l}\text { Variable precipitation, exposed to extreme winter weather } \\
\text { events, contested levels of grazing-mediated degradation }\end{array}$ & $\begin{array}{l}\text { Highly variable precipitation, mixed or contested levels of } \\
\text { grazing-mediated degradation }\end{array}$ \\
\hline $\begin{array}{l}\text { Key socio-economic } \\
\text { characteristics }\end{array}$ & $\begin{array}{l}\text { Non-exclusive tenure with the exception of small areas for use } \\
\text { as a winter shelter, poorer livelihoods than urban population in } \\
\text { middle income country, non-colonial context, high proportion } \\
\text { of national population, remote governance and distance to } \\
\text { markets }\end{array}$ & $\begin{array}{l}\text { Exclusive tenure to the level of the household, poorer } \\
\text { livelihoods than urban population in wealthy country, colonial } \\
\text { context, small proportion of national population, remote } \\
\text { governance and distance to markets }\end{array}$ \\
\hline $\begin{array}{l}\text { Examples of important } \\
\text { pastoral values }\end{array}$ & $\begin{array}{l}\text { security, freedom and choice, social relations, social boundary } \\
\text { between urban and pastoral, "urban population doesn't } \\
\text { understand" }\end{array}$ & $\begin{array}{l}\text { Independence, social boundary between urban and pastoral, } \\
\text { speak for own property, "urban population doesn't } \\
\text { understand" }\end{array}$ \\
\hline $\begin{array}{l}\text { Examples of important } \\
\text { non-government values }\end{array}$ & $\begin{array}{l}\text { Conservation of productive vegetation and fauna, livelihood } \\
\text { development }\end{array}$ & Biodiversity conservation (especially fauna) \\
\hline $\begin{array}{l}\text { Examples of important } \\
\text { urban values }\end{array}$ & $\begin{array}{l}\text { Meat hygiene, reduced sandstorms, pastoralists as holders of } \\
\text { culture, pastoralists as unsophisticated }\end{array}$ & $\begin{array}{l}\text { Conservation, multi-use drylands, increased Indigenous rights } \\
\text { and recreation, "outback mythology," pastoralism as extractive }\end{array}$ \\
\hline
\end{tabular}

(2020b), Bennett et al. (2020), and Brown et al. (2020). Addison et al. (unpub data) consists of a mixture of qualitative and quantitative data from semi-structured interviews with randomly selected pastoralists from Mongolia's steppe region $(n=102$, year $=2019$, provinces $=$ Tuv, Dundgobi, Bulgan, Akhangai, Khentii, Selenge and Sukhbaatar). These surveys were developed after both pilots $(n=10)$ and focus groups $(n=4)$ that focused on understanding pastoralist aspirations, livelihood status, and livelihood challenges.

\section{Case Study Description}

A set of specific characteristics underpin the coupled social-ecology of drylands (Stafford Smith, 2008). More obvious characteristics include high climatic variability and unpredictability, and low productivity. However, drylands are also characterized by sparse populations, a small pool of expertise, remote governance and distant markets (Stafford Smith et al., 2007; Stafford Smith, 2008). These characteristics create unequal power dynamics that can both contribute to, and compound, significant tensions between pastoral and non-pastoral populations. These tensions have implications for the development, implementation and compliance with formal institutions, like those seeking to promote pro-conservation livestock management. Here, we choose two dryland case studies that share these characteristics (see Table $\mathbf{1}$ for a summary), but differ markedly in land tenure arrangements, market integration and cultural history, to better explore potential interactions between how pastoralists conceptualize a meaningful livelihood, how these might conflict with broader social values, and possible entry points for institutional interventions.

\section{Australian Drylands}

Over $70 \%$ of Australia's landmass is under pastoral production (Holmes, 2002) with $<1 \%$ of the population controlling natural resource management in over $60 \%$ of the continent (MacLeod and McIvor, 2006). Much of Australia's pastoral land is arid/semiarid (precipitation $\leq 500 \mathrm{~mm}$ per annum) with the north of this region (north of $27^{\circ} \mathrm{S}$ ) experiencing rainfall that is highly variable on a global scale (van Etten, 2009). Most of this land consists of beef cattle grazing on unimproved pastures.

Australia's Human Development Index is amongst the highest in the world (United Nations Development Programme, 2019). It is unclear where dryland pastoralists sit in relation to Australia's overall Index, but Australia's rural and remote population has comparatively higher levels of socioeconomic disadvantage, with lower incomes, fewer years of education, higher rates of disability and relatively poor access to health professionals when compared to the urban population (Australian Bureau of Statistics, 2018). Nevertheless, pastoralists and their families have access to a strong social welfare system that includes, for example, financial support for low income families and educational programmes for remote schooling. Alternative employment options are available nationally, with Australia's unemployment rate currently and historically being relatively low on a global scale (The World Bank, 2019).

Rights to utilize drylands for pastoral purposes are predominately exclusive to the level of an individual or company (Australian Trade Investment Commission, 2020). However, these rights are generally limited to a pastoral land-use and on the whole do not preclude other land-uses such as mining or Indigenous Native Title (except in the Queensland freehold pastoral drylands), particularly in areas that remain "unimproved." In pastoral leasehold areas, the primary responsibility for adequate natural resource management falls on the State. In freehold pastoral areas, the title holder holds ultimate responsibility for natural resource management but pastoralists in both types of tenure are still subject to relevant environmental laws. Despite pastoralism only existing since European colonialism, pastoralists are generally not legally required to manage country in line with Indigenous understandings of land management (such as through use of fire). This is the case even in pastoral leasehold areas under Native Title, a land-use that has increased significantly in recent years.

Many of the drylands, and especially in central and northern areas, are in remote locations with limited transport infrastructure while a summer monsoonal influence in northern 
areas can influence access to markets. The transport logistics, along with the type of cattle suited to the region, mean that the industry operates in segments that are less integrated with the domestic Australian beef market. Instead the industry is specialized into particular export market segments notably live cattle trade and lean beef export markets.

Direct influence and investment by government in the Australian pastoral drylands has declined, with a shift toward community-based service provision (Hunt, 2003). Individuals have been encouraged to engage in local natural resource management activities (such as Landcare-Landcare Australian, 2020), largely on a voluntary basis. Non-government organizations (NGOs) have invested heavily to address the resource constraints of the government-sponsored conservation estate; many of the most recently acquired pastoral properties are run by NGOs rather than by government-based conservation agencies, though often with government funding.

\section{Mongolian Steppe}

Like Australia, over $70 \%$ of Mongolia's landmass is used for agriculture, the majority of which is under an extensive pastoral land-use. Precipitation is low, with a mean of $227.3 \mathrm{~mm}$ pa (The World Bank Group, 2020). Both the significant intraannual climatic variability and a latitudinal climatic gradient (Kakinuma et al., 2019) drive differences in pastoral land-use. In northern areas where precipitation is less variable and pasture productivity is higher, pastoralists practice transhumance or are stable geographically. In contrast, in southern areas where pasture productivity is low but also variable, pastoralists are largely nomadic. In both areas, Winter shocks (" $d z u d s$ ") caused by factors such as extremely cold temperatures, deep snow, poor preceding growth periods, overgrazing or a combination of these, occur periodically.

Variations in access to services and markets have also led to differences in human geography. The Human Development Index, which takes a value between zero and one, ranges from 0.664 to 0.695 in pastoral areas, with the highest value for the eastern region and the lowest for the more remote western region (Mongolian Statistical Information Service, 2019). The HDI for Ulaanbaatar for comparison is 0.822 (Mongolian Statistical Information Service, 2019). Average monthly household income is similarly lower in pastoral areas than the national capital. There are high levels of un- or underemployment and lack of alternative employment opportunities in general for pastoralists.

Despite lower incomes in the pastoral sector, pastoralism is a much more significant economic activity in Mongolia than Australia. The sector employs about 285, 000 people in a population of about 3.2 million (Mongolian Statistical Information Service, 2019). Agriculture, of which the majority is pastoralism, contributes about $11 \%$ to the gross domestic product. It has also provided a significant livelihood security net to Mongolia, with a mass exodus of people from urban areas absorbed into the pastoral sector during the economic reforms of the 1990s (Mearns, 2004).

The economic reforms of the 1990s also involved the State de-investing from the agricultural sector. Livestock were privatized, but forage access was not. As such, land tenurerelated institutions are more reflective of biophysical variability in Mongolia than Australia. Whilst pastoralists can be granted exclusive rights to small plots of land for shelter in Winter, access to pasture is non-exclusive (Addison et al., 2020a). Pastoralists have the legal right to track forage availability within their district and, with agreements between district leaders, outside their district if required by biophysical conditions. Local officials are given significant discretionary powers to manage grazing pressures, although they are often not resourced sufficiently to allow policing. Wealthier international development agencies and non-government organizations have grown to support the pastoral sector, with an additional interest in environmental management and conservation amid growing concerns about livestock numbers.

\section{PASTORALIST AND SOCIAL IMAGININGS: ALIGNMENT AND MISALIGNMENT}

\section{Australian Drylands}

Despite its relative recentness as a land-use, the Australian population continues to attribute cultural meaning to the maintenance of pastoralism (Holmes, 2002; Hamblin, 2009). Simultaneously, there is both greater societal scrutiny of the landuses that currently exist (see Russell-Smith and Sangha, 2019 for an example) and an increasing desire for pastoral areas to become more multi-use. Multi-use, in the Australian dryland context, tends to consist of an increased emphasis on biodiversity conservation, outdoor recreation and Indigenous management of country for cultural and environmental outcomes (Quinn, 2001; Hunt, 2003; Russell-Smith and Sangha, 2018). As Maclean (2009) notes, Australia's drylands should be understood as cultural, contested and dynamic spaces. Struggles over land-use are often not over property rights in the legal sense, but rather moralities linked to relationship to land.

Non-pastoralists with a stake in pastoral areas of the Australian drylands have deployed different versions of the "outback mythology," contemporary frontier ideologies that use landscapes as a loci of identity, meaning and belonging, in the general struggle for control of natural resources. The valueorientations of dryland Indigenous people, pastoralists and urban conservationists are incredibly differentiated despite a shared interest in dryland natural resources (Holmes and Day, 1995). In relation to an increased societal interest in conservation, these value orientations, with subsequent implications for livelihood strategies, have often alienated pastoralists from the conservation discussion (Gill, 2003; Addison and Pavey, 2017). This alienation has occurred even in the absence of empirical evidence for their contribution to declining biodiversity. For example, despite the value-driven, widely held belief linking agricultural production and small mammal decline (Williams and Price, 2010), reliable evidence establishing grazing as the primary factor for the loss of biodiversity, rather than a possible contributing factor, is lacking (Fensham et al., 2010; Frank, 2010; Frank et al., 2012; Silcock and Fensham, 2019). 
Perceived links between pastoralism and declining biodiversity in dryland Australia have resulted in the greater involvement of conservation NGOs. This involvement has likely exacerbated pastoralist alienation. Many pastoralists perceive that areas taken out of agricultural production for conservation purposes are then poorly managed for biodiversity (Holmes and Day, 1995; O'Connor and Bond, 2012). The cynicism produced by such a practice may both limit the impact of environmental programmes on pastoral land, and undermine confidence in participatory strategies for engaging pastoralists with conservation in off-lease areas (CSIRO, 2003). One example is the pastoral industry's concern over the $\$ 9$ million given by the Australian government to R. M. Williams for the purchase of Henbury Station in central Australia as a Carbon Sequestration venture. A strong sense of place attachment can render such buy-outs an existential threat to pastoralists (Hunt, 2003). The lack of evidence that such ventures can return a profit, concern over land management, the loss of productive grazing land, and suspicion that the societal emphasis on multi-use values precludes pastoralism, can also create concern (NTCA Open Letter to political parties, July 2012; Northern Territory Cattlenews 13(3):9, July 2012):

Purchases such as these threaten the long term future of our industry by removing critical mass and skills from the region. They distort the property market because they operate under a different set of rules and with resources not available to other potential purchasers, they prevent new entrants to the industry and they fly in the face of other programs which are intended to encourage on-farm conservation and multiple land use.

(Rohan Sullivan, NTCA President, Sullivan, 2012).

The livelihood aspirations of dryland pastoralists are complex, encapsulating much more than finances. Russell-Smith and Sangha (2018) found that typical northern pastoral enterprises were unprofitable and carried significant debt as measured by earnings after interest before tax (EABT). Profits are typically much lower than other agricultural communities in Australia (Holmes and Day, 1995). Maclean (2009) also noted that pastoralists in the Tanami Desert face social livelihood challenges including poor access to health and education services, and a high reliance on government assistance subsidies and resources. The strong orientation of dryland pastoralists toward intrinsic, expressive and social values (as opposed to instrumental values where farming is viewed as a means to obtain income and security), and the pastoral lifestyle that provides them with these values, may partially compensate for such continuing economic and social hardships (Holmes and Day, 1995). In particular, an extremely high value is placed on independence (though it is important to note this does not conflict with a strong social orientation).

Pastoralists of Australia's drylands have a strong sense of identity and self-worth. This has flow on effects for what constitutes both a meaningful livelihood, and deployed livelihood strategies. Holmes and Day (1995) noted that South Australian pastoralists closely identify with a distinctive way-of-life and its equally distinctive landscape. This sense of identity is socially "global" with dryland pastoralists comprising a cohesive social group that transcends individual property boundaries. This can often result in pro-environmental behavior, particularly in relation to trans-boundary issues such as the control of weeds, feral animals or fire that may affect neighbors. However, identification with landscape and landscape processes is generally very localized with knowledge about landscape highly specific and place-based (Gill, 1997; Maclean, 2009; Addison and Pavey, 2017). As Gill (1997) notes:

\begin{abstract}
"Amongst pastoralists this highly specific knowledge has engendered an ethic that one doesn't talk about anybody else's properties or pass comment on what other pastoralists should or should not do.... To presume to speak for another's property is not only to speak for land you do not know, but is to ride roughshod over the knowledge and experience of another. One does not only transgress property boundaries but also social and personal space. To speak for another's land is to intrude on that person's or family's self. Respect for these boundaries is strong amongst the pastoral community." p. $59-60$
\end{abstract}

Dryland pastoralists are very conscious of their custodial role with often a rich and contextually nuanced understanding of ecological dynamics on their property. However, the high value placed on local knowledge accumulated through time can create tensions with the increasing social desire for pastoral drylands to become more multi-use, and to be managed in a particular manner to achieve particular cultural and environmental values. Land management decisions and practices embody cultural epistemologies that are diverse (Maclean, 2009), and mismatched perceptions about landscape ecology, biodiversity, and the appropriate tools and policies for dryland management, have created tension between pastoralists and other stakeholders (Abel et al., 1998; Lankester, 2012).

Specifically, the push toward the incorporation of greater social values throughout specific land management practices are "transgress[ing] property boundaries but also social and personal space" (Gill, 1997, p. 60) in a way that is considered disrespectful by pastoralists, even if the aspiration of "good" natural resource management is ultimately shared. For example, Addison and Pavey (2017) found that most pastoralists in dryland Australia assigned great conservation value to small mammals, and there was a strong willingness to engage in conservation activities for small mammals that did not conflict strongly with other livestock production goals. However, they also highlighted a potentially significant subpopulation who valued small mammals but did not wish to engage in formal conservation programs due to relationship tensions with potential implementing stakeholders. Amongst a cohort that values independence so highly, poorly thought through social transgression of values risks disengagement from these broader social values, and institutions. Pastoralist emphasis on independence and local knowledge, and distrust of those without these, suggests institutions seeking to encourage pastoralists toward managing for a broader set of values must do so in ways that carefully respect pastoralist knowledge, are brokered by those who are local and trusted, and acknowledge high levels of independence (Addison and Pavey, 2017). 


\section{Mongolian Steppe}

In Mongolia, the social, cultural and economic importance of dryland pastoralism is so strong as to be enshrined in the country's collective identity (Barcus, 2018); the 1992 Constitution states that "livestock is the national wealth of the country and subject to State protection." Unlike Australia, the pastoral and urban population in Mongolia is closely linked through family and friend networks (Sneath, 2006), with pastoralists and pastoral culture still visible in urban areas via annual festivals such as Naadam, and the significant ger (yurt) suburbs surrounding the capital of Ulaanbaatar. Nevertheless, tensions are growing between pastoral and non-pastoral actors, particularly with the growth in mining, retreat of the State from the pastoral sector and advancement of international organizations in the subsequent vacuum, and the redistribution of the population that accompanied a transition to the market economy (e.g., Barcus, 2018).

Recent decades have led to an increasing divergence in urban and pastoral value orientations (Sneath, 2006). Urban understandings of pastoralists sometimes employ a mythology similar to that of the Australian "outback"; proximity and understanding of nature, pastoralism as strongly underpinning national identity and culture, and with pastoralists hardworking and sincere (Sneath, 2006). However, urban framings of pastoral life are also inconsistent. Negative representations tend to relate to lack of refinement or sophistication, with rural culture disrespected for the same traditionality for which it is applauded (Sneath, 2006).

As in Australia, negative representations of pastoralists also tend to relate to perceptions around extractive or damaging land management practices (Upton, 2020), perceptions that have not always been fully informed by available evidence (e.g., Addison et al., 2012).

Even more so than in Australia, the growing presence of NGOs are both symptomatic of, and drivers of, contestation (Barcus, 2018; Upton, 2020). For example, the tangled intersections of pastoral-related values often manifest strongly where international NGO-sponsored community natural resource management groups have been established. The institutions of community natural resource management groups, even when designed in a participatory manner with pastoralists, often weaken with time or are not strongly acknowledged by those for whom they most strongly relate (Addison et al., 2013). This is perhaps as attempts to strengthen property rights following externally derived understandings of community have created institutional misfits neglecting complex relationships between labor, land, and livestock (Undargaa, 2016).

Mismatched intentions between community based natural resource management design and pastoralist involvement are sometimes underpinned by contestation around the condition, causes of change and the meaning ascribed to changes in the drylands (see Addison et al., 2013). Pastoralists differ in both their perceived contribution to landscape degradation in Mongolia, and the ways in which they believe they can influence grassland condition. In the desert steppe, it is common for pastoralists to emphasize the role of climatic variability on pasture availability rather than overgrazing (Addison et al., 2012).
In more densely populated and climatically equilibrial steppe areas, pastoralists are more likely to identify overgrazing as a cause of environmental change but are often unsure as to how they personally may address the issue (Addison unpublished data). Upton (2020) also notes the role of local animist and Buddhist cultural norms and ontologies related to relations of care between pastoralists and the landscape via spiritual entities. Some pastoralists link land degradation to trespass upon these beliefs through, for, example, digging the soil for mining (Addison et al., 2012).

Whilst domestic and international non-government organizations tend to strongly value conservation on the Mongolian steppe (Upton, 2020), the urban domestic population has a more diverse set of values. For example, when Ulaanbaatar residents were asked to choose between attributes related to grassland condition-the proportion of pastoralists in the total population (as an indicator of pastoral culture), sandstorm frequency and meat safety-they were much more concerned with, first, meat safety for human consumption and, secondly, sandstorm frequency than they were with grassland condition (Bennett et al., 2020). For this urban population, and in contrast to NGO values, physical health and safety may be much more important than environmental conservation per se.

For the pastoral population, good social relations and security are important aspects of a meaningful livelihood. Addison et al. (2020b) noted the importance of social cohesion, mutual respect, good gender and family relations, and the ability to help others, such as children, for steppe pastoralists. Secure access to natural and other resources, safety, and living in a predictable and controllable environment are considered equally important (also see, for example, Addison et al., 2013; Lkhagvadorj et al., 2013). A primary livelihood strategy resulting from these values is to maximize the absolute number of animals that survive $d z u d$, a strategy with empirical support if a pastoralist's ultimate livelihood vision is to continue as a pastoral household (Oniki and Dagys, 2017).

The primacy of the pastoral existence (or, perhaps, subsistence) strategy may well reflect a lack of alternative livelihood options. Whilst many pastoralists may wish for their children to take up alternative livelihoods, many pragmatically note that there are a lack of alternatives (see also Yano, 2012). Mongolian pastoralists emphasize the desire to secure their own children's livelihoods, including assisting them to get an education and profession with some pastoralists wishing their children's professions would be split between the city and herding (Addison et al., 2020b). These desires reflect the mixed perspectives Mongolian pastoralists have toward the sustainability of pastoral livelihoods. Some believe strongly for both cultural and economic reasons in the need for, and viability of, pastoralism in general and for their children. Others are concerned about the high level of livelihood risk associated with pastoralism including production, health and risks of declining resources (Dorjburegdaa et al., 2013). Many external commentators also frequently frame Mongolian pastoralism in terms of an existential crisis (The Economist, 2010; Reuters, 2018). 
For many Mongolian pastoralists, freedom and choice are also considered important parts of livelihoods (Addison et al., 2020b), with a pastoral land-use providing them with both. This freedom and choice is akin to the "independence" valued by Australian dryland pastoralists. Likewise, this emphasis on freedom and choice does not necessarily conflict with the high value placed on social relations or social values. Pastoralist-onpastoralist conflict in relation to access to grazing lands has been frequently cited as being of concern to pastoralists in Mongolia (Addison et al., 2013) with pastoralists often expressing a desire for more pastoralist-to-pastoralist collaboration (Addison et al., 2020b). However, this desire for increased collaboration is unlikely to extend to the urban population; similar to the Australian drylands, there is a social boundary between Mongolian pastoralists, the urban population, non-government organizations and the State that may make policy interventions designed to achieve greater social values in the drylands quite difficult.

\section{RECOGNIZING VALUES AND LIVELIHOOD ASPIRATIONS IN POLICY INTERVENTIONS}

As these two case studies illustrate, pre-existing values and understandings of a meaningful livelihood amongst pastoralists tend to involve independence, security, risk aversion and longevity as pastoralists. These values directly inform livelihood strategies that can misalign with broader social values for the drylands. Formal institutions seeking to encourage pastoralists to manage for these broader social values must appreciate the strong emphasis on values other than profit maximization, and be brokered by those who are local and trusted.

Various policy mechanisms have been introduced in dryland Australia and Mongolia to increase socially desired values, primarily environmental services, with limited results. Carrot ("persuasion") and stick ("penalty") policy controls were, and still often are, considered to be important tools for addressing degradation issues in areas under a pastoral land-use with perceived benefits including fully specified solutions, and straightforward monitoring and compliance (Sahl and Bernstein, 1995). In Mongolia, and to a lesser extent Australia, a strong involvement by the State was historically accompanied by significant levels of support such as subsidized mobility and fodder provision in Mongolia's case. Whilst Mongolia's grassland condition is believed to have declined since the 1990s (Addison et al., 2012), with mixed trends in the Australian drylands (Bastin and the ACRIS Management Committee, 2008), internationally these types of institutional tools have tended to produce limited results, with weaknesses including rigidity, oversimplification, lack of adaptability and inefficiency (Sahl and Bernstein, 1995). In the drylands where climatic variability is high and populations are sparse, these constraints have been particularly strong.

More recent institutions that devolve responsibility over natural resource management to the level of the individual or local community have also produced mixed results. Community based natural resource management institutions attempt to promote strong relations between pastoralists, and there is some evidence that social benefits have ensured from these institutions in Mongolia (Fernandez-Gimenez et al., 2015; Ulambayar et al., 2017; Ulambayar and Fernandez-Gimenez, 2019). However, known constraints such as volunteer burn-out (e.g., Byron et al., 2011), perceived inability to translate group activities into demonstrable landscape-level environmental benefits (e.g., Addison et al., 2013; Tennent and Lackie, 2013), multilevel tensions within nested governance systems (Tennent and Lackie, 2013) and a growing conceptualization of environmental degradation as a form of market failure (see Lockie, 2009, 2012), suggest that community based natural resource management alone may not be sufficient.

When choosing whether to become involved in natural resource management, primary producers measure the likely net benefits that a programme or activities will provide pre-existing livelihood goals including material wealth and security, environmental protection/enhancement, social approval/acceptance, personal integrity and ethics, and work/lifestyle balance (see Pannell et al., 2006). Programme design attributes are also important (Pannell et al., 2006; Moon et al., 2012; O'Connor and Bond, 2012; Waudby et al., 2012). In drylands under a pastoral land-use, the implementation of risk-management strategies under a variable climate tends to be orientated toward large herd sizes, lifestyle goals and longer-term economic sustainability rather than short-term profit (Espeland et al., 2020). This suggests that there is an opportunity to better design natural resource management institutions in ways that more accurately reflect pastoralists' pre-existing goals, potentially overcoming some of the weaknesses of prior institutions.

In dryland Australia, the development of institutions that respect pastoralist independence and recognize their autonomy over their pastoral lease may facilitate shift in land-use toward the greater social desire of multi-use rangelands, particularly in the provision of greater environmental services. The potential involvement of pastoralists in small mammal conservation provides an example. The high labor and material costs of conservation in dryland Australia, combined with the high level of spatio-temporal variability of natural resources and threats (Pavey et al., 2017), means pastoralists may be the most cost effective labor source for the temporally strategic management of small mammal refuges during the so-called "early bust" phase of wildlife population cycles. Addison and Pavey (2017) noted that the management of a key threat to small mammals, cat and fox predation, did not conflict with other pastoralist livelihood aspirations and there was a high willingness, and existing action, for pastoralist management of these predators. Reflecting livelihood values being broader than income alone, Addison and Pavey (2017) found that financial incentives did not increase stated willingness to engage with predator control. Instead, strong brokering and support by local "insiders" may provide for the desire for greater State support for conservation management (Waudby et al., 2012) if done so in a manner that respects autonomy and independence.

In Mongolia, whilst various institutions seek to maintain or improve grassland condition through fluctuating seasonal conditions, the devolution of responsibility for managing livelihood risk from the State to individual pastoralists and 
general retreat of the State from the pastoral sector has meant that local formal institutions supporting pastoralist livelihoods have been weak. Policies that enhance security in the face of high levels of biophysical variability, and promote strong relations between pastoralists, may prove attractive to Mongolian pastoralists, even if they have minimal impact on household wealth. The pilot Payment for Ecosystem Services scheme described by Upton (2020) provides one example of an institutional intervention more cognisant of pastoralist livelihood values. The scheme seeks to link international purchasers of carbon credits with community-based "sellers" of carbon; in Mongolia's case a pasture user group committed to changing herd management in ways that increase stored carbon. To re-frame Upton (2020), a carbon based Payment for Ecosystem Services institution may exploit an alignment between pastoralist livelihood aspirations unrelated to carbon, and the carbon related values of the international community. By being community-based and "bottom-up," rather than targeted at the level of the individual, it may also strengthen pastoralist relations whilst still providing the informational and financial support needed to initiate and maintain the changes in herd management needed to improve environmental services. As Upton (2020) noted, non-monetary incentives such as participation in governance were considered at least as important to many pastoralists involved in the pilot as the potential payments themselves. These features of importance to pastoralists are likely to take on more prominence in future land use policies. For instance Brown et al. (2020) explore pastoralists' stated responses to a cap and trade livestock scheme. In recognition of the querying of what constitutes community in pastoral drylands (Hogg, 1992), such a scheme may allow for some level of collective responsibility and cohesion (in the setting of the overall cap) but also acknowledge and facilitate individual actions and values (in deciding whether to buy or sell more or less quota). The design of such instruments would be crucial in determining whether they do align with pastoralist values as well as their effectiveness in dealing with landscape condition and pastoralist livelihoods.

\section{CONCLUSION}

In drylands under a pastoral-land-use, geographical factors like high levels of climatic variability and sparse populations combine with social factors like high levels of independence to mean that pastoralist understandings of "the good life" can relate more to livelihood security and autonomy than immediate material wealth. These values can misalign with the imaginings of the non-pastoral population for drylands that are managed for a broader set of values, such as conservation or meat safety. Engagement with institutions designed to fulfill broader social values are dependent upon the ability of these institutions to help

\section{REFERENCES}

Abel, N., Ross, H., and Walker, P. (1998). Mental models in rangeland research communication and management. Rangeland J. 20, 77-91. doi: $10.1071 /$ RJ9980077 pastoralists meet their value-based livelihood goals. Whilst there may be striking commonalities in values between pastoral groups, context-specific understandings of pastoralist values and visions can highlight appropriate policy options that may shift socialecological systems toward those that are more socially desirable, with the design of these options requiring an understanding of unique combinations of pastoral and societal values, biophysical parameters and institutional contexts.

\section{DATA AVAILABILITY STATEMENT}

The raw data supporting the conclusions of this article will be made available by the authors, without undue reservation.

\section{ETHICS STATEMENT}

The studies involving human participants were reviewed and approved by University of Queensland Human Research Ethics Committee 2017000180. Written informed consent for participation was not required for this study in accordance with the national legislation and the institutional requirements.

\section{AUTHOR CONTRIBUTIONS}

JA led the drafting of the manuscript, design, data collection and analysis for Australian case study, design and analysis of Mongolian case study. CB contributed to writing manuscript, contribution of intellectual property in the Mongolian case study, project manager of Mongolian case study project. CP contributed to writing manuscript, contribution of intellectual property in the Australian case study, project manager of Australian case study project. E-OL co-design of Mongolian case study contributed to writing manuscript, project coordination of Mongolian case study. DB co-design of Mongolian case study, data collection and analysis for Mongolian case study, project coordination of Mongolian case study. LD co-design of Mongolian case study, data collection for Mongolian case study. All authors contributed to the article and approved the submitted version.

\section{ACKNOWLEDGMENTS}

We would like to thank the pastoralists who were involved in the research cited throughout this paper. We acknowledge the support of our respective institutions (James Cook University, the University of Queensland, the CSIRO Land and Water, Australian National University and the Mongolian University of Life Sciences). In particular, we acknowledge the Australian Centre for International Agricultural Research, and Territory NRM who provided funding for this research. 
Addison, J., Davies, J., Friedel, M., and Brown, C. (2013). Do pasture user groups lead to improved rangeland condition in the Mongolian Gobi Desert? J. Arid Environ. 94, 37-46. doi: 10.1016/j.jaridenv.2013.02.009

Addison, J., Friedel, M., Brown, C., Davies, J., and Waldron, S. (2012). A critical review of degradation assumptions applied to Mongolia’s Gobi Desert. Rangeland J. 34, 125-137. doi: 10.1071/RJ11013

Addison, J., Lkhagvadorj, E., Dorjburegdaa, L., Bao, Z., and Ping, L. (2020b). "Herders as agents of change," in Common Grasslands in Asia - A Comparative Analysis of Chinese and Mongolian Grasslands, ed C. Brown (Cheltenham: Edward Elgar Publishing).

Addison, J., and Pavey, C. (2017). Alignment between values of dryland pastoralists and conservation needs for small mammals. Conserv. Biol. 31, 2, 331-342. doi: $10.1111 /$ cobi.12803

Addison, J., Stoeckl, N., Larson, S., Jarvis, D., Bunuba Dawangarri Aboriginal Corporation, R. N. T. B. C., Ewamian Aboriginal Corporation, R. N. T. B. C., et al. (2019). The ability of community based natural resource management to contribute to development as freedom and the role of access. World Dev. 120, 91-104. doi: 10.1016/j.worlddev.2019.04.004

Australian Bureau of Statistics (2018). 2033.0.55.001 - Census of Population and Housing: Socio-Economic Indexes for Areas (SEIFA). LATEST ISSUE Released at 11:30 AM (CANBERRA TIME) 27/03/2018. Available online at: https:// www.abs.gov.au/ausstats/abs@.nsf/Lookup/by\%20Subject/2033.0.55.001 2016 Main\%20Features IRSAD\%20Interactive\%20Map 16 (accessed April 04 2020).

Australian Trade and Investment Commission (2020). Pastoral Leases. Available online at: https://www.austrade.gov.au/land-tenure/Land-tenure/pastoralleases (accessed April 04 2020).

Barcus, H. (2018). Contested space, contested livelihoods: a review of Mongolia's pastureland management and land-tenure reform. Geogr. Rev. 108, 1, 138-157. doi: 10.1111 /gere. 12246

Bastin, G., and the ACRIS Management Committee. (2008). Rangelands $2008-$ Taking the Pulse, published on behalf of the ACRIS Management Committee by the National Land \& Water Resources Audit, Canberra.

Bennett, J., Ping, L., Bao, Z., Lkhagvadorj, E., and Bukhbat, D. (2020). "Understanding policies and preferences," in Common Grasslands in Asia A Comparative Analysis of Chinese and Mongolian Grasslands, ed C. Brown (Cheltenham: Edward Elgar Publishing). doi: 10.4337/9781788974059.00014

Bhatnagar, Y., Wangchuk, R., Prins, H., VanWieren, S., and Mishra, C. (2006). Perceived conflicts between pastoralism and conservation of the Kiang Equus kiang in the Ladakh Trans-Himalaya, India. Environ. Managem. 38, 934-941. doi: 10.1007/s00267-005-0356-2

Brown, C., Bennett, J., Quanghua, Q., Durjburegdaa, L., Addison, J., Gombosuren, U., et al. (2020). "Strengthening policy incentives," in Common grasslands in Asia - A comparative analysis of Chinese and Mongolian Grasslands, eds C. Brown (Cheltenham: Edward Elgar Publishing).

Byron, I., Curtis, A., and Lockwood, M. (2011). Exploring burnout in Australia's Landcare program: a case study in the Shepparton region. Soc. Nat. Res. 10, 901-910. doi: 10.1080/089419201753242805

Chambers, R., and Conway, R. (1992). Sustainable rural livelihoods: practical concepts for the $21^{\text {st }}$ century. (IDS discussion paper), No. 296. 127-130.

Cocklin, C., Mautner, N., and Dibden, J. (2007). Public policy, private landholders: perspectives on policy mechanisms for sustainable land management. J. Environ. Managem. 85, 986-998. doi: 10.1016/j.jenvman.2006.11.009

CSIRO (Commonwealth Scientific and Industrial Research Organisation) (2003). Assessing the impact of Landcare activities on natural resource condition. Review of the National Landcare Program. Canberra, ACT: Australian Government Department of Agriculture, Fisheries and Forestry.

Dorjburegdaa, L., Hauck, M., Dulamsuren, C., and Tsogtbaatar, J. (2013). Twenty years after decollectivization: mobile livestock husbandry and its ecological impact in the Mongolian forest-steppe. Human Ecol. 41, 725-735. doi: 10.1007/s10745-013-9599-3

Espeland, E., Schreeg, L., and Porensky, P. (2020). Managing risks related to climate variability in rangeland-based livestock production: what producer driven strategies are shared and prevalent across diverse dryland geographies? J. Environ. Management 255:889. doi: 10.1016/j.jenvman.2019.109889

Fensham, R. J., Fairfax, R. J., and Dwyer, J. M. (2010). Vegetation responses to the first 20 years of cattle grazing in an Australian desert. Ecology 91, 681-692. doi: 10.1890/08-2356.1
Fernandez-Gimenez, M., Batkhishig, B., Batbuyan, B., and Ulambayar, T. (2015). Lessons from the dzud: community-based rangeland management increases the adaptive capacity of Mongolian herders to winter disasters. World Dev. 68, 48-65. doi: 10.1016/j.worlddev.2014.11.015

Frank, A. (2010). The ecological impacts of cattle grazing within spinifex grasslands and gidgee woodlands in the Simpson Desert, central Australia. ( $\mathrm{PhD}$ thesis, University of Sydney), 258.

Frank, A. S. K., Dickman, C. R., and Wardle, G. M. (2012). Habitat use and behaviour of cattle in a heterogenous desert environment in central Australia. Rangeland J. 34, 319-328. doi: 10.1071/RJ12032

Gill, N. (1997). "The contested domain of pastoralism: landscape, work and outsiders in Central Australia," in Tracking Knowledge - North Australian Landscapes: Studies in Indigenous and Settler Knowledge Systems, eds D. B. Rose and A. Clarke (Darwin: North Australian Research Unit), 50-67.

Gill, N. (2003). Environmental (re)education and local environmental knowledge: statutory ground-based monitoring and pastoral culture in Central Australia. Rangeland J. 25, 85-104. doi: 10.1071/RJ03002

Hamblin, A. (2009). Policy directions for agricultural land use in Australia and other post-industrial economies. Land Use Policy 26:4. doi: 10.1016/j.landusepol.2009.01.002

Hebinck, P. G. M., and Bourdillon, M. (2002). “Analysing livelihoods," in Women, Man and Work. Rural Livelihoods in Central-Eastern Zimbabwe, eds P. Hebink and M. Bourdillon (Harare: Weaver), 1-13.

Hogg, R. (1992). NGOs, pastoralists and the myth of community: three case studies of pastoral development from East Africa. Nomadic Peoples 30, 122-146.

Holmes, J. (2002). Diversity and change in Australia's rangelands: a postproductivist transition with a difference? Trans. Institute Br. Geogr. NS 27, 362-384. doi: 10.1111/1475-5661.00059

Holmes, J., and Day, P. (1995). Identity, lifestyle and survival: value orientations of South Australian pastoralists. Rangeland J. 17, 111-127.

Hundie, B. (2010). Conflicts between Afar pastoralists and their neighbours: triggers and motivations. Intern. J. Conflict Violence 4, 134-148.

Hunt, L. (2003). Opportunities for the future in Australia’s grazed rangelands. Rangeland J. 25, 183-195. doi: 10.1071/RJ03015

Kakinuma, K., Yanagawa, A., Sasaki, T., Rao, M. P., and Kanae, S. (2019). Socioecological interactions in a changing climate: a review of the Mongolian pastoral system. Sustainability (Switzerland), 11, 1-17. doi: 10.3390/su11215883

Kearney, F., McAllister, R., and MacLeod, N. (2012). Conservation and grazing in Australia's north-east: the bridled nailtail wallaby. Pastoralism 2:20. doi: 10.1186/2041-7136-2-20

Landcare Australian (2020). Available online at: https://landcareaustralia.org.au/ (accessed April 04 2020)

Lankester, A. (2012). Self-perceived roles in life and achieving sustainability on family farms in north-eastern Australia. Austr. Geograph. 43, 233-251. doi: $10.1080 / 00049182.2012 .706202$

Leach, M., Mearns, R., and Scoones, I. (2009). Challenges to community-based sustainable development: dynamics, entitlements, institutions. IDS Bull. 28, 4-14. doi: 10.1111/j.1759-5436.1997.mp28004002.x

Lkhagvadorj, D., Hauck, M., Dulamsuren, C.h., and Tsogtbaatar, J. (2013). Pastoral nomadism in the forest-steppe of the Mongolian Altai under a changing economy and a warming climate. J. Arid Environ. 88, 82-89. doi: 10.1016/j.jaridenv.2012.07.019

Lockie, S. (2009). Agricultural biodiversity and neoliberal regimes of agrienvironmental governance in Australia. Curr. Sociol. 57, 407-426. doi: $10.1177 / 0011392108101590$

Lockie, S. (2012), "Market-based resource managements policy and environmental uncertainty: outsourcing risk calculation," in Thomas Measham and Stewart Lockie Risk and Social Theory in Environmental Management, eds T. Measham, and S. L. Risk (Clayton, MO: CSIRO Publishing), 79-90.

Maclean, K. (2009). Re-conceptualising desert landscapes: unpacking historical narratives and contemporary realities for sustainable livelihood development in central Australia. GeoJournal 74, 451. doi: 10.1007/s10708-008-9234-9

MacLeod, N., and McIvor, J. (2006). Reconciling economic and ecological conflicts for sustained management of grazing lands. Ecol. Econ. 56, 386-401. doi: 10.1016/j.ecolecon.2005.09.016

Mearns (2004). Sustaining livelihoods on Mongolia's pastoral commons: insights from a participatory poverty assessment. Dev. Change 35:1. doi: $10.1111 / j .1467-7660.2004 .00345 . x$ 
Mongolian Statistical Information Service (2019). Available online at: https://www. en.nso.mn/ (accessed April 04 2020).

Moon, K., Cocklin, C. (2011). Participation in biodiversity conservation: motivations and barriers of Australian landholders. J. Rural Studies 27, 331-342. doi: 10.1016/j.jrurstud.2011.04.001

Moon, K., Marshall, N., and Cocklin, C. (2012). Personal circumstance and social characteristics as determinants of landholder participation in biodiversity conservation programs. J. Environ. Manag. 113, 292-300. doi: 10.1016/j.jenvman.2012.09.003

O'Connor, P., and Bond, A. (2012). Options for Stewardship in the South Australian Rangelands. Consultancy Report to Department of Environment, Water and Natural Resources South Australia for the Trans-Australia Eco-Link Initiative by O'Connor NRM.

Oniki, S., Dagys, K. (2017). Recovery from a winter disaster in Tov province of Mongolia. J. Arid Environ. 139, 49-57. doi: 10.1016/j.jaridenv.2016.12.010

Osano, P., Said, M., de Leeuw, J., Ndiwa, N., Kaelo, D., Schomers, S., Birner, R., Ogutu, J. (2013). Why keep lions instead of livestock? Assessing wildlife tourism-based payment for ecosystem service involving herders in the Maasai Mara, Kenya. Nat. Resource Forum 37, 242-256. doi: 10.1111/1477-8947.12027

Ostrom, E. (2019). A general framework for analysing sustainability of socialecological systems. Science 325-5939, 419-422. doi: 10.1126/science.1172133

Pannell, D., Marshall, G., Barr, N., Curtis, A., Vanclay, F., Wilkinson, R. (2006). Understanding and promoting adoption of conservation practices by rural landholders. Austr. J. Experim. Agric. 46, 1407-1424. doi: 10.1071/EA05037

Pavey, C., Addison, J., Brandle, R., Dickman, C., McDonald, P., Moseby, K., et al. (2017). The role of refuges in the persistence of Australian dryland mammals. Biol. Rev. 92, 647-664. doi: 10.1111/brv.12247

Quinn, M. (2001). Rights to the rangelands: European contests of possession in the early $20^{\text {th }}$ century. Rangeland J. 23, 1, 15-24. doi: 10.1071/RJ01011

Reuters (2018). Available online at: https://www.reuters.com/article/us-mongoliaclimatechange-herders/urban-nomads-mongolian-herders-battle-newfuture-as-leave-the-land-for-the-city-idUSKBN1I400N

Ribot, J., Peluso, N. (2003). A theory of access. Rural Sociol. 68, 153-181. doi: 10.1111/j.1549-0831.2003.tb00133.x

Russell-Smith, J., Sangha, K. (2018). Emerging opportunities for developing a diversified land sector economy in Australia's northern savannas. Rangeland J. 40, 315-330. doi: 10.1071/RJ18005

Russell-Smith, J., Sangha, K. (2019). Beneficial land sector change in far northern Australia is required and possible - a refutation of McLean and Holmes (2019). Rangeland J. 41, 363-369. doi: 10.1071/RJ19030

Sahl, J., Bernstein, B. (1995). Developing policy in an uncertain world. Intern. J. Sustainable Dev. World Ecol. 2, 124-135. doi: 10.1080/13504509509469894

Scoones, I. (2009). Livelihoods perspectives and rural development. J. Peasant Stud. 36, 171-196. doi: 10.1080/03066150902820503

Sen, A. (1999). Development as Freedom. New York, NY: Alfred Knopf.

Silcock, J., Fensham, R. (2019). Degraded or just dusty? Examining ecological change in arid lands. Bioscience 69, 508-522. doi: 10.1093/biosci/biz054

Sneath, D. (2006). "The rural and the urban in pastoral Mongolia," in Mongols from Country to City eds O. Bruun and L. Narangoa (Denmark: NIAS Press), $140-161$.

Stafford Smith, M. (2008). The 'desert syndrome' - causally-linked factors that characterise outback Australia. Rangeland J. 30, 3-14. doi: 10.1071/RJ07063

Stafford Smith, M., McKeon, G., Watson, I. Henry, B., Stone, G., Hall, W., et al. (2007). Learning from episodes of degradation and recovery in variable Australian rangelands. Proc. Natl. Acad. Sci. U.S.A. 104, 20690-20695. doi: 10.1073/pnas.0704837104

Sullivan, R. (2012) NTCA AGM President's report. In: Northern Territory Cattlemen's Association Year in Review 2011-2012, eds L. Bowen and T. Page (Walsh Media Services; ABrdoewlanid) 6-13

Taylor, M. (2002). The shaping of San livelihood strategies: government policy and popular values. Dev. Change 33, 467-488. doi: 10.1111/1467-7660.00263

Tennent, R., and Lackie, S. (2013). Market-based instruments and competitive stewardship funding for biodiversity conservation: the achievable reality. Austr. J. Environ. Manag. 20, 6-20. doi: 10.1080/14486563.2012.751641
The Economist (2010). In Mongolia, Many Nomads Despair. Available online at: https://www.economist.com/banyan/2010/03/05/in-mongolia-manynomads-despair (accessed April 04 2020).

The World Bank (2019). Unemployment, Total (\% of Total Labor Force) (Modeled ILO Estimate). Available online at: https://data.worldbank.org/indicator/SL. UEM.TOTL.ZS (accessed April 04 2020).

The World Bank Group (2020). Climate Change Knowledge Portal Country Mongolia. Available online at: https://climateknowledgeportal.worldbank.org/ country/mongolia/climate-data-historical (accessed April 04 2020).

Thebaud, B., Batterbury, S. (2001). Sahel pastoralists: opportunism, struggle, conflict and negotiation. A case study from eastern Niger. Global Environ. Change 11, 69-78. doi: 10.1016/S0959-3780(00)00046-7

Ulambayar, T., Fernandez-Gimenez, M. (2019). How communitybased rangeland management achieves positive social outcomes in Mongolia: a moderated mediation analysis. Land Use Policy 82, 93-104. doi: 10.1016/j.landusepol.2018.11.008

Ulambayar, T., Fernandez-Gimenez, M., Baival, B., Batjav, B. (2017). Social outcomes of community-baed rangeland management in Mongolian steppe ecosystems. Conserv. Lett. 10, 317-327. doi: 10.1111/conl.12267

Ulvevadet, B., Hausner, V. (2011). Incentives and regulations to reconcile conservation and development: thirty years of governance of the Sami pastoral ecosystem in Finnmark, Norway. J. Environ. Managem. 92, 2794-802. doi: $10.1016 /$ j.jenvman.2011.06.026

Undargaa, S. (2016). Pastoralism and common pool resources - rangeland comanagement, property rights and access in Mongolia'. Routledge 272:779. doi: $10.4324 / 9781315726779$

United Nations Development Programme (2019). Human Development Data. Available online at: http://hdr.undp.org/en/data (accessed April 04 2020).

Upton, C. (2009). "Custom" and contestation: land reform in post-socialist Mongolia. World Dev. 37, 1400-1410. doi: 10.1016/j.worlddev.2008.08.014

Upton, C. (2020). Conserving natures? Co-producing payments for ecosystem services in Mongolian rangelands. Dev. Change 51, 224-252. doi: 10.1111/dech.12549

van Etten, E. (2009). Inter-annual rainfall variability of arid Australia: greater than elsewhere? Austr. Geographer 40:75. doi: 10.1080/00049180802657075

Van Hecken, G., Bastiaensen, J. (2010). Payments for ecosystem services: justified or not? A political view. Environ. Sci. Policy 13, 785-792. doi: 10.1016/j.envsci.2010.09.006

Waudby, H. S., Petit, S., Robinson, G. (2012). Pastoralists' perceptions of biodiversity and land management strategies in the arid Stony Plains region of South Australia: implications for policy makers. J. Environ. Management 112, 96-103. doi: 10.1016/j.jenvman.2012.07.012

Williams, J., Price, R. (2010). Impacts of red meat production on biodiversity in Australia: a review and comparison with alternative protein production industries. Animal Product. Rev. 50:9132. doi: 10.1071/A N09132

Yano, S. (2012). Overeducated? The Impact of Higher Education Expansion in Post-Transition Mongolia (PhD Thesis. Columbia University).

Yongo, E., Abila, R., Lwenya, C. (2010). Emerging resource use conflicts between Kenyan fisherman, pastoralist and tribesmen of Lake Turkana. Aquatic Ecosystem Health Managem. 13, 28-34. doi: 10.1080/14634980903 578308

Conflict of Interest: The authors declare that the research was conducted in the absence of any commercial or financial relationships that could be construed as a potential conflict of interest.

Copyright () 2020 Addison, Brown, Pavey, Lkhagvadorj, Bukhbat and Dorjburegdaa. This is an open-access article distributed under the terms of the Creative Commons Attribution License (CC BY). The use, distribution or reproduction in other forums is permitted, provided the original author (s) and the copyright owner(s) are credited and that the original publication in this journal is cited, in accordance with accepted academic practice. No use, distribution or reproduction is permitted which does not comply with these terms. 